DOI: 10.1515/jolace-2015-0005

\title{
Digital portfolio in building teaching efficacy of pre-service teachers
}

\author{
Ivana Cimermanová \\ University of Prešov, Slovakia \\ ivana.cimermanova@unipo.sk
}

\begin{abstract}
The paper discusses the role of e-portfolio in the development of reflective thinking in a group of pre-service English as a foreign language teachers. It stresses the benefits it can bring (e.g. autonomous learning, cooperative learning - the author highlights the social context of e-portfolio) as well as presents the threats and risks it might bring based on the own experience of the author. The results of this case study showed that the process of eportfolio building can enhance professional development, self-confidence and the ability to self-reflect own work and progress. The author indicates also the possibilities of its use not only in the groups of pre-service teacher trainers but also in the groups of in-service teachers.
\end{abstract}

Keywords

e-portfolio, self-reflection, self-confidence, cooperative learning

We cannot teach people anything; we can only help them discover it within themselves.

Galileo Galilei

\section{Introduction}

Essential teaching skills are frequently discussed issue. Kyriacu (2007) summarises (based on other researchers, e.g. Child, Perott, Waterhouse, Wrag) seven essential teaching skills - lesson planning, lesson presentation, lesson management, classroom climate, discipline, assessing pupil's progress, reflection and evaluation (self-evaluation). Self-monitoring and self-assessing, evaluating of own current teaching practice has a significant impact on the educational process, learner and mainly the teacher/himself/herself. We have mentioned (see above) seven essential teaching skills and it is especially the ability to receive and perceive objective self-reflection, accepting constructive criticism is one of the basic skills that are necessary to develop the six other skills.

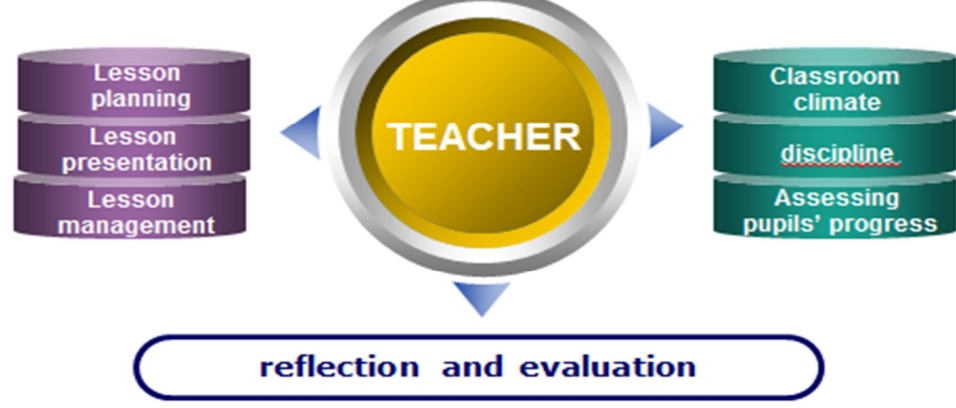

Fig. 1 Essential teaching skills (Kyriacu, 2007) 
Černotová (e.g. 2010) have mainly been interested in questions concerning teacher trainers at schools, mentors, the quality of teaching practice and cooperation between the universities and teachertraining schools. She provides in-depth analysis and draws our attention to significance of reflection and analysis of the lessons on the efficacy of pre-service teachers. In her studies she reported that the biggest problems students (pre-service teachers) see in insufficient number of lessons and insufficient analysis of their lessons; and supervisors would like to receive more support from the university, especially methodology teachers.

\section{Teaching practice and self-development}

Reflection is closely connected with feedback, ability to analyse our activities and to deduce the conclusions leading to improvement of future practice. In educational process, every lesson is a source of information about the way we teach, about the way learners learn as well as a source of information about us.

Self-reflection and self-evaluation belong among the key components of a teacher's personal and professional development. The significant part of this process is the analyses, evaluation of the process and drawing the results followed by the conclusions and setting the aims for further teaching practice. Self-reflection enables teachers to reflect their performance, to learn more about their strengths and weaknesses. The analyses and evaluation of the situation contributes to the satisfaction and brings new challenges. The process itself leads towards self-development.

It has been mentioned that self-evaluation is a significant component of self-development. There are various Self-evaluation conceptions and here we bring Petty (2009, p. 517), who discusses the experiential learning cycle (see also Kolb) cycle and defines four phases:

1. Concrete experience. Petty stresses the importance of experience of teaching. At the same time he mentions that lack of practice "is often not the major difficulty in learning to teach".

2. Reflect on experience. Petty highlights that "Reflection involves a systematic and objective evaluation of the student's 'concrete experience'" (2009, p. 338)

3. Abstract conceptualisation. In this phase teachers should answer the questions such as - Why was the lesson effective? or Why did I fail to achieve one of the set aims? The result of this phase are the generalised reasons of the success and failure.

4. Plan active experimentation. "Bearing in mind what you have learned from experience, you ask questions such as 'What would I do differently if I taught that lesson again?', 'What shall I do differently next lesson as a result of what I have learned?' and 'What new methods, styles or techniques should I try out in order to improve my teaching?” (Petty, 2009, p. 517)

Learning as such is a cyclical process and thus every lesson leads us towards further experimentation, gaining new experience that must be analysed and the further steps should be suggested and verified.

Hupková and Petlák (2004, p. 33-34) define six steps that lead from self-reflection to self-development:

1. self-reflection

2. self-evaluation

3. self-confidence

4. self-control

5. self-regulation

6. self-creation

\section{Perceived teaching efficacy}

In this context the terms personal teaching efficacy and general teaching efficacy should be mentioned. Gavora (2010) defines them as follows: 
1. „Personal teaching efficacy (PTE) represents a teacher's belief that he/she possesses the skills and abilities to facilitate student learning, that is, it is the teacher's overall sense of his/her own teaching effectiveness". It is represented by the statement If a pupil's grade improve, it is because I found a way how to adjust teaching him/her.

2. „General teaching efficacy (GTE) represents the belief that teaching (as an organisational form of education) can affect pupils positively, even in light of external factors or conditions such as low motivation or poor home environment". He provides a sample item for the Teacher Efficacy Scale (TES) instrument: A teacher is very limited in what he/she can achieve because it is the home preparation that shapes a pupil's motivation. (Gavora, 2010, p.22).

Gavora (2008) claims that the way teacher perceives his/her abilities is the most significant selfregulation feature in his/her work - teacher's self-evaluation has an influence on his/her approach and attitude towards pupils and the quality of his/her activity in the class. The teacher activates his/her academic and professional competences based on the level of self-regulation and acts accordingly. Based on the academic studies and research he summarises the basic findings about the teacher perceived efficacy:

- teacher himself/herself creates his/her perception about his//her efficacy and it is not given

- it is created relatively early - as soon as in the stage of preparation for teaching profession at the university and is gradually developed at the beginning of teaching

- it is to certain extent a subconscious, normally teacher does not intentionally analyse it.

- it is relatively firm (permanent), does not change rapidly and based on accidental moments

- it can reach different grades. It can be perceived as a scale from low to high persuasion (belief)

- it is specific in particular situations. It can be discussed as a teacher perceived efficacy according to the type of school, subjects taught, and the particular educational situations (Gavora, 2008).

Pajares (2002, n. p.) states that "Teacher self-efficacy has become an important construct in teacher education, and teacher educators should continue to explore how these beliefs develop, what factors contribute to strong and positive teaching efficacy beliefs in varied domains, and how teacher education programs can help preservice teachers develop high teacher self-efficacy." Gavora \& Majerčíková (2012) point out that the personal efficacy is the persuasion about the ability to reach something in one's profession without regard to his/her real competences. It involves such constructs as the ability to influence the pupils' results, their discipline, ability to solve the learners' learning problems at school, etc.. The perceived efficacy effects teacher's decisions in what and how (s)he acts in the class. High selfefficacy results in selecting more difficult task, high level of employment and involvement, and good emotional attitude. On the other hand teachers with low sense of efficacy are frequently described as those who emphasize rigid control of classroom behavior, and rely on extrinsic inducements and negative sanctions to get students to study (see Pajares, 2002).

Concerning the teacher efficacy and its impact on the educational results it has been mentioned that it is created in the phase of pre-service preparation. The research showed that „Pre-service teachers have reported an increase in teacher efficacy after their student teaching experience (Hoy, 2000; Hoy \& Spero, 2005; Woolfolk, 1998). However, the length of the student teaching experience, whether one semester or two semesters, does not appear to impact perception of teacher efficacy (Chambers \& Hardy, 2005). Egger (2006, p. 15) reported that „Novice teachers' perception of teacher efficacy tends to decline during the first year of teaching with increasing concerns about student discipline (Hoy, 2000; Hoy \& Spero, 2005; Onafowora, 2004).

Numerous studies have attempted to explain the significance of efficacy beliefs and Pajares (2002, n.p.) suggests that the efficacy beliefs of teachers are associated to their instructional practices and to various student outcomes and we select some of them: 
- "Teachers' beliefs of personal efficacy affect their instructional activities and their orientation toward the educational process.

- Preservice teachers' sense of teacher efficacy is related to their beliefs about controlling students.

- Teacher self-efficacy also predicts student achievement and students' achievement beliefs across various areas and levels".

As it has been indicated teaching efficacy is linked to self-regulation what is a part of selfdevelopment, similarly as self-reflection and self-evaluation. The results of the researches draw our attention to a group of pre-service teachers who form their attitudes and beliefs during their university studies.

\section{Portfolio in language teaching}

The term portfolio is traditionally explained as a collection of investments that are owned by a person or organisation. This term nowadays is more broadly understood and it also defines the term as a set of pictures or other pieces of work that an artist, photographer etc..

Granberg (2010) understands portfolio as a tool that can be used in education and identifies three borders between e-portfolio discourses - portfolio as an archive, portfolio for assessment, portfolio for learning (see fig. 2).

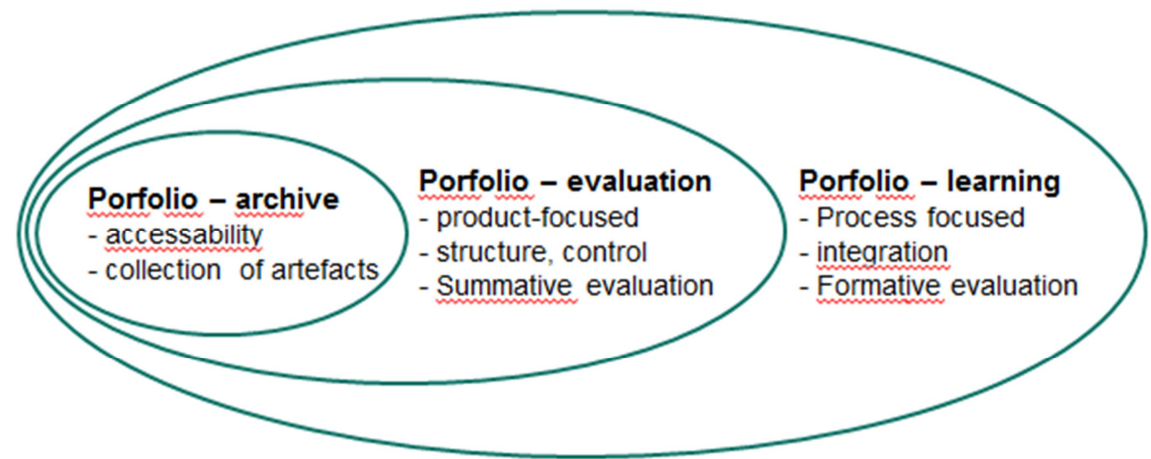

Fig. 2 Three identified borders between e-portfolio discourses: as an archive, for summative assessment and as a portfolio for learning (Granberg, 2010).

Crow and Mitchel (2006, p.12) categorise 5 types of portfolia:

1. assessment portfolios (examples of the owner's work for viewing by others for assessment purposes);

2. showcase portfolios (the best examples of the owner's work, usually formatted in date order);

3. development portfolio (allows the owner to monitor and plan their own development;

4. reflective portfolios (allows the owner to review their own development; typically shared when the owner is applying for a job, or wanting to highlight work to other;

5. hybrid portfolios (combination of two or more of the above).

Use of portfolio is not a new topic at our schools. European language portfolio has been used since 1997 when it was experimentally introduced to Slovak schools. It is a collection of pupil's materials that document his/her language abilities and at the same time it provides a space for recording one's own language progress. Compilation, organisation and work with portfolio is inevitably connected with the process of material evaluation and self-evaluation what is connected with the learner autonomy and development of critical thinking. The language portfolio consists of Language biography, Language passport and Dossier. 
Ten years later EPOSTL (The European Portfolio for Student Teachers of Languages) was introduced to University students - pre-service English language teachers (the document is available online at http://www.ecml.at/epostl). The EPOSTL is a document intended for students undergoing their initial teacher education which encourages them to reflect on the didactic knowledge and skills necessary to teach languages, helps them to assess their own didactic competences and enables them to monitor their progress and to record their experiences of teaching during the course of their teacher education (see Newby et al, 2007a, 2007b) and its aim is to encourage students to reflect on their competences, to help prepare students for their future profession in a variety of teaching contexts; to promote discussion among students, and between the teacher and students, mentor, supervisor and students, to facilitate self-assessment and to provide an instrument which helps chart progress.

The main components of EPOSTL are personal statement (philosophy and motivation, general questions related to teaching); second part is a self-assessment section mapping what students can do, facilitating reflection and self-assessment (the items can be found in ELP in the form of 'can-do' descriptors, see figure below) and the third section is Dossier in which students collect their materials that form the evidence of progress and it enables to record examples of work connected with teaching, e.g. lesson plans, feedbacks (from students, mentors, teachers).

Students' portfolios are used at the teacher training faculties (especially to map their progress and problems during teacher training but also as the outcomes in other subjects). We received an interesting feedback from Lucia, our student, who answered the question about the possible use of portfolio after graduating university as a novice teacher positively but added Yes I will, but I am happy, nobody reads it anymore and I do not need to follow the prescribed structure. It is surprising as the students were informed that portfolio is written for them and not for the mentor or methodology teacher, that it is not necessary to type them etc. On the other hand we tried to help them by suggesting the possibilities how to solve particular situations, to encourage them if needed. This was done with the aim to teach them how important and beneficial communication and open discussion, sharing experience with the colleagues can be. Compiling portfolio leads students to critical thinking, rational and pragmatic approach to problem solving and to building the competence to setting the clear aims.

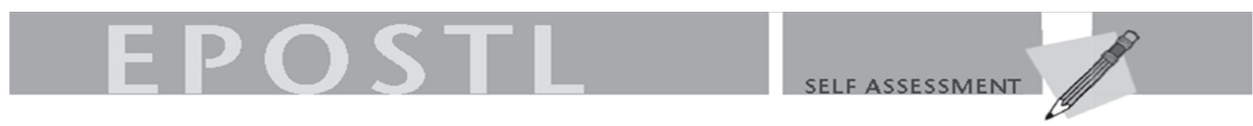

A. Identification of Learning Objectives

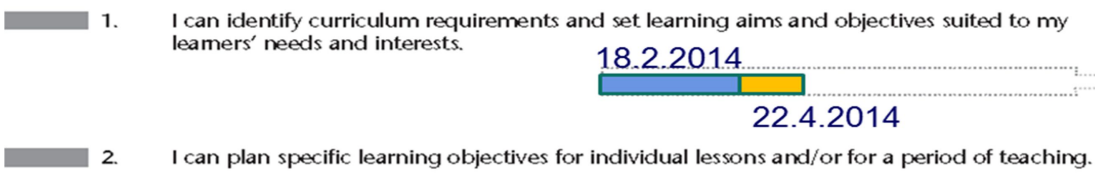

2. I can plan specific learning objectives for individual lessons and/or for a period of teaching.

3. I can set objectives which challenge learners to reach their full potential.

I can set objectives which take into account the differing levels of ability and special educational needs of the learners.

Fig. 3 EPOSTL. Self-assessment section

Teacher trainees are, compared to in-service teachers, constantly forced by their situation and context to learn, observe, analyse the lessons as a part of their compulsory education. Students must 
systematically self-reflect their work and draw conclusions for their future career. They keep records, documents about their work and progress in portfolio. They describe the context of their teaching, lesson plans and the analysis of their lessons, self-evaluation, material description, learner profiles etc..

The in-service teachers must be intrinsically strongly motivated to realise those steps regularly.

This part describes portfolio and its benefits for teaching practice what Blake et al. (1995, in Takona, 2002) summarises as „... a systematic and organized collection of evidence used by the teacher and student to monitor growth of the student's knowledge, skills, and attitudes in a specific subject area". Portfolio helps to create and build own teaching philosophy, methods, approaches. At the same time it enables to present the quality of teacher and at the same time it documents his/her professional development. In case of objective reflection and analyses it can identify and formulate the areas for improvement. Next part moves on to describe in greater detail electronic portfolio and the phases of its compilation.

\section{ePortfolio and phases of its compilation}

Electronic portfolios can be created using different technologies. Here we mention the selected possibilities:

- Digital portfolio (e.g. CD, materials digitalised to electronic media)

- Blog (standard blog, that enables the entrance of the community to the content, still there is usually a fixed structure and its recording and keeping may sometimes be difficult)

- ePortfolio websites - portals, web sites created for this purpose (frequently as a result of projects)

- iWebfolio - electronic portfolio management system, commercial software (student aimed) Edgerton, Hutchings \& Quinlan (1991, p. 4-6, in Kaplan, 1998) summarise advantages of teacher portfolio in 4 points:

1. Captures the complexity of teaching (portfolio contains evidence and reflection in the context of what is being taught to whom under what conditions; portfolio can present a view of a teacher's development over time, etc.)

2. Places responsibility for evaluation in presenting their own teaching accomplishments so that evaluation is not something done "to" them (teachers present results of their work and thus they are directly involved in evaluating their own work; portfolio enriches the evaluation and extends the evaluation beyond the classification of learners, etc.).

3. Encourages improvement and reflection (portfolio creations automatically leads to reflection, what enables comparison of the expected and real outcomes; in case that portfolio is accessible to other teachers, it enables the mutual enrichment).

4. Fosters a culture of teaching (portfolio can provide a rich and contextualised source of evidence about teaching achievements that can be used for a variety of purposes, including evaluation, improvement, summary of faculty careers, and defining "good teaching" in a department" (Kaplan, 1998, p. 4).

Portfolio goes beyond the regular evaluation as it covers the evidence from different sources, as e.g. syllabus, student work samples, self-reflection, research reports, teaching and teacher development. The process of material selection leads teacher to think about his/her teaching, methodology, approaches what leads to the improvement in teaching practice.

As one of the main benefits we see that it enables colleagues to mutually enrich each other. Making portfolio accessible to other colleagues enables them to comment it, to discuss its content, evaluate it and learn from each other.

Ur (2009, p. 6) based on the Kolb's theory suggests the so-called enriched reflection. Kolb defines four modes of learning, namely: concrete experience, reflective observation, abstract conceptualisation and active experimentation. Concrete experience is the basis for observation and reflection that lead to and are followed by abstract conceptualisation and generalisation. This cycle is further closed by an active experimentation in concrete situation. This cycle entails further concrete experimentation. Ur 
$(2009,7)$ also suggests to enrich the model, resp. every mode by "external sources of input". She highlights that this process of reflection can be shortened in case of use of experienced teachers, experts, researchers and from reading, video recordings etc. (see Fig. 4).

To create space for enriched reflection we may use virtual learning environment (VLE) where one of the components is ePortfolio. Teachers have to realise not only advantages but also drawbacks and risks that use of technologies bring, especially certain technical skills is a must, problem with internet success, availability (and price) of a system.

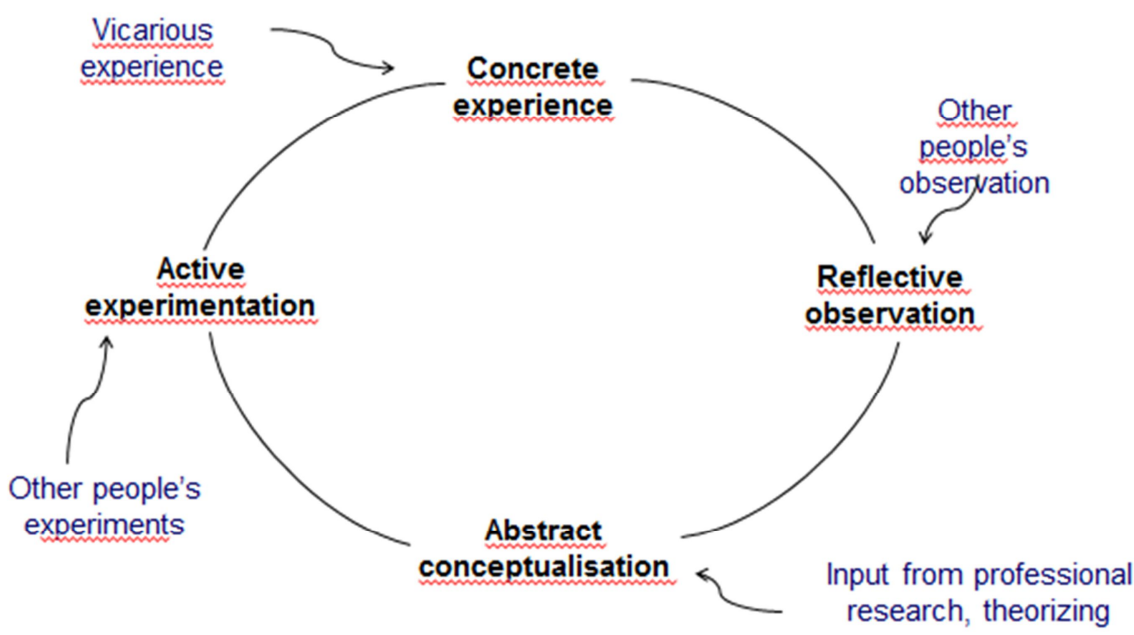

Fig. 4 Enriched reflection (Penny Ur, 2009)

\section{Use of e-portfolio in pre-service teacher training}

One of the main rules in portfolio compilation is not to create materials for portfolio but to use portfolio to organise materials that were created for teaching. Portfolio compilation is not a short-term activity; it has been already mentioned that it is a document that maps the process and progress and thus it is not possible to create it ad hoc. Trunda (2012) defines four phase of teacher portfolio compilation. The first phase presents data collection. The second phase is self-evaluation of a teacher. Based on the collected document he/she should be able to reflect his/her activities and set the areas of possible improvement. In the third phase the portfolio should be presented to the institution (e.g. school management in case of in-service teachers, methodology teacher in case of pre-service teachers). The open dialogues leads towards the clarification of attitudes, values, aims, tools and instruments for their achievement. The questions of usually structured dialogue are known in advance. The teacher sets the plan of professional development in the fourth phase. Plan can be done together with some more experienced teacher.

Currently, there are many institutions that develop their own environment for creation digital portfolios and/or recording materials directly into the developed system. At the University of Presov we use (as an alternative to face to face communication and/or to support in-class lessons) learning management system (LMS) Moodle. Regarding EFL classes and communication the tools that are most frequently used are forum (sometimes wiki) where students e.g. can write feedbacks on their lessons, observations and then community (methodology teacher and classmates) can comment on it, and chats where student synchronously discus the topics (chats are recorded and available for later retrieval). In this way they enrich the self-evaluation by their opinions, recommendations and alternatives. 


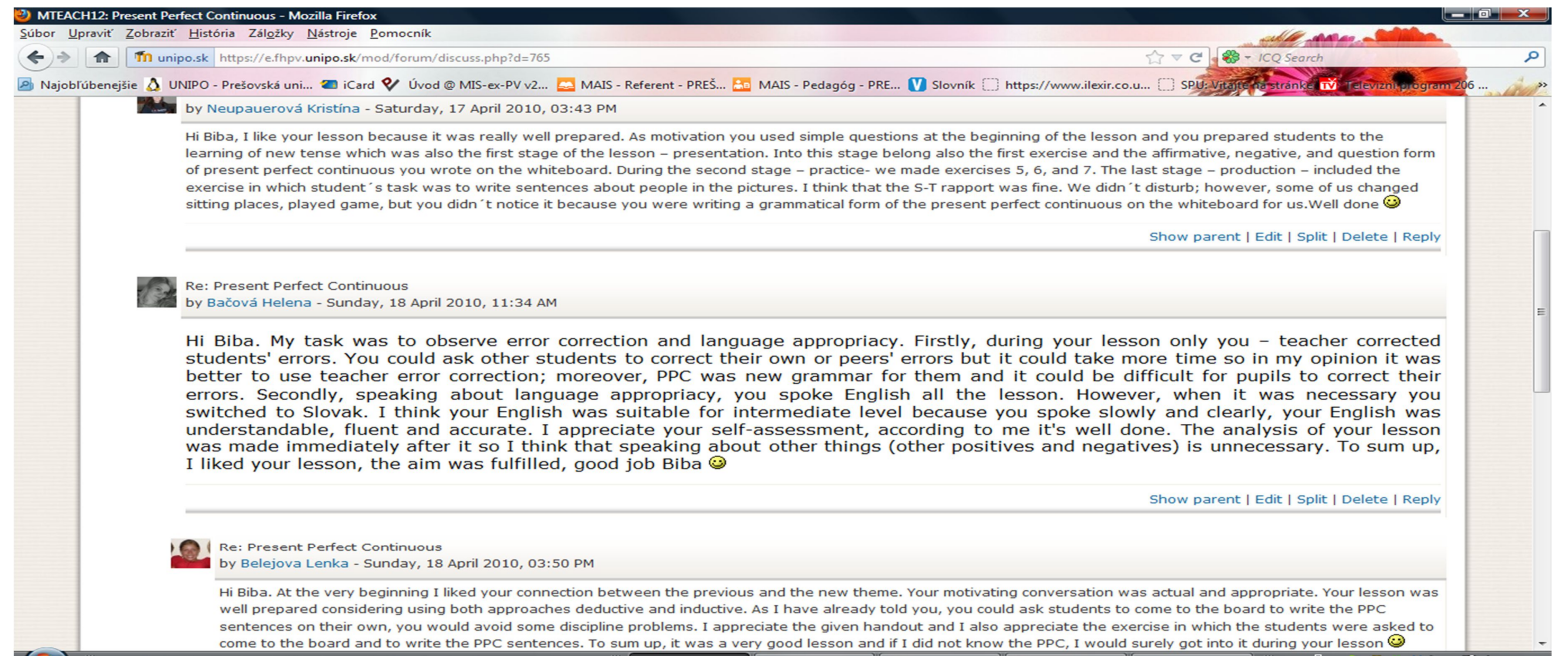

Fig. 5 Sample of feedback in LMS Moodle

Similarly, the forum can be also used for academic debates. Asynchronous communication provides a space for discussion but also it is persistent and thus anyone in a group can reach data also afterwards. Different tools enable teacher to lead statistics about the students' performance. The fact that the messages are permanent leads learner to higher attention (compared to in-class discussion) and thus they think more about what to publish, how to formulate it, how to sound academically, how to contribute to a discussion.

\section{ePortfolio in perspective}

Essential teaching skills must be developed in the pre-graduation preparation and students must understand the necessity of self-reflection and feedback for their personal growth and teacher development. It is equally important for them to learn to direct, to face, to take constructive criticism (both, positive and negative).

VLE creates the space for enriching the dimensions of traditional paper portfolio with further components and/or tools that help to build autonomous development of future teachers but also provide an access of the community to their materials. Using VLE provides the space for forum implementation (discussed above), introduction of the e-courses that can be used for self-study (the courses can also be identified based on the self-evaluation), e-reflection as an individual component (based on the structure of VLE and e-portfolio). 


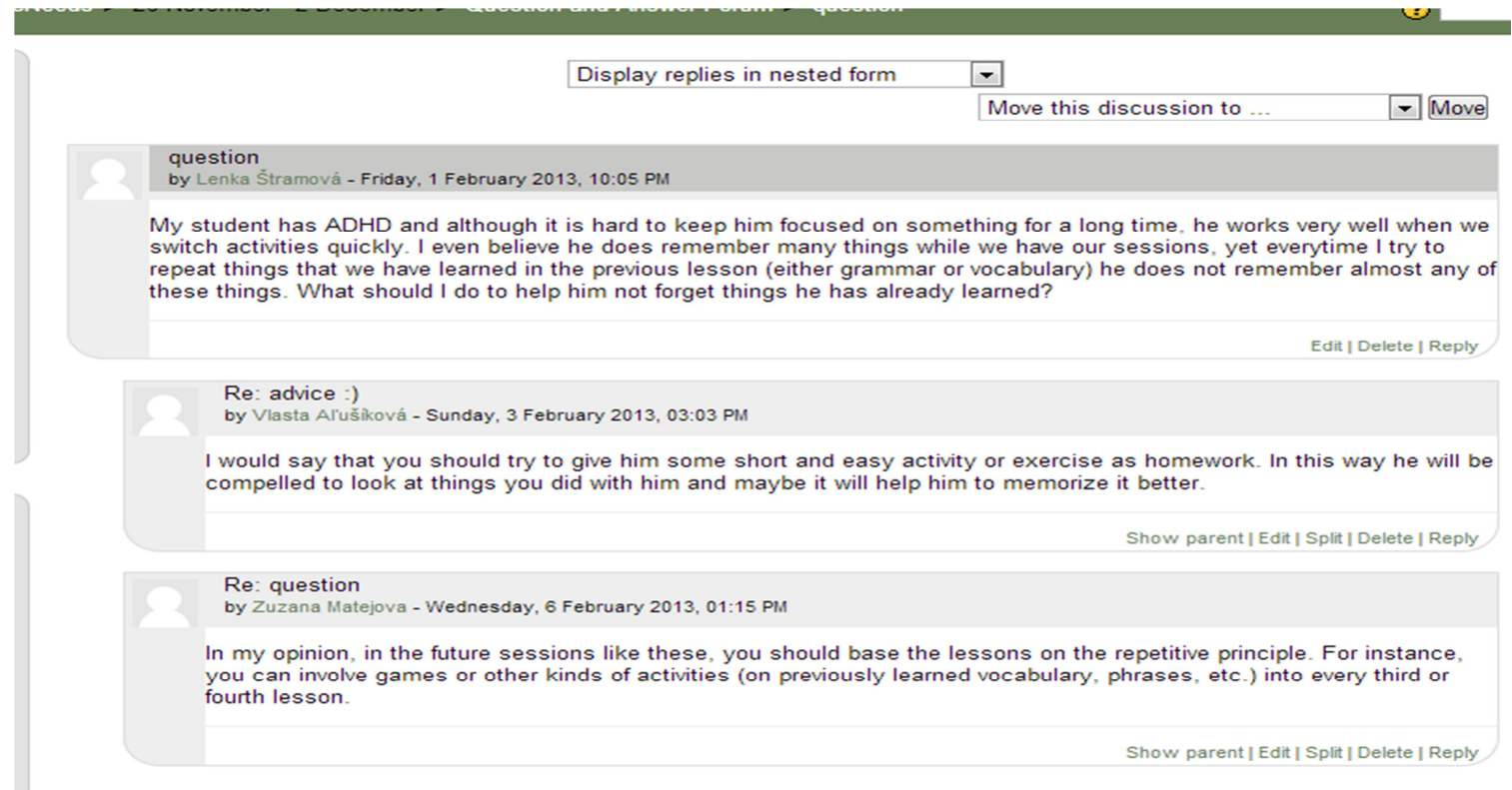

Fig. 6 Sample of discussion in LMS Moodle

One of the most important benefits is that VLE and e-portfolio offer is the possibility of the entrance of the teacher training supervisor into the reflection and self-reflection process (see Fig. 8). Discussion is thus open not only to the trainee, his/her student-colleagues, methodology teacher but also the person who may have a significant influence on student and his attitude towards future profession who is his/her teacher training supervisor (an in-service teacher).

\section{Autonomous development of pre-service teachers}

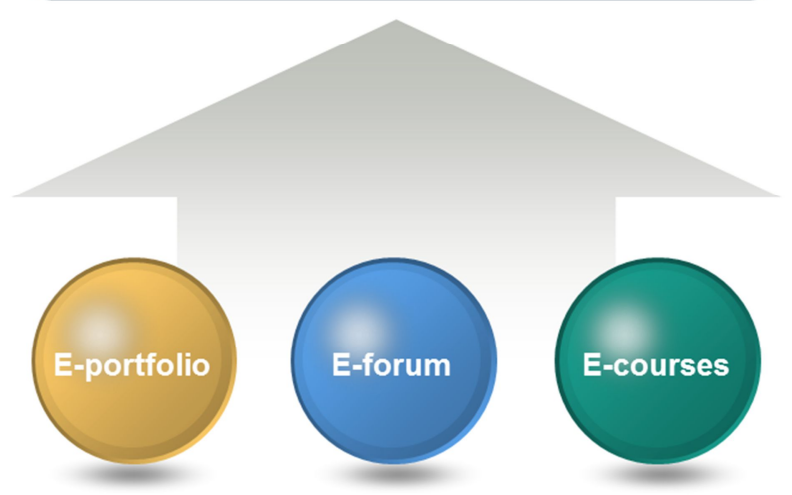

Fig. 7 Possible components of VLE for teacher trainees 


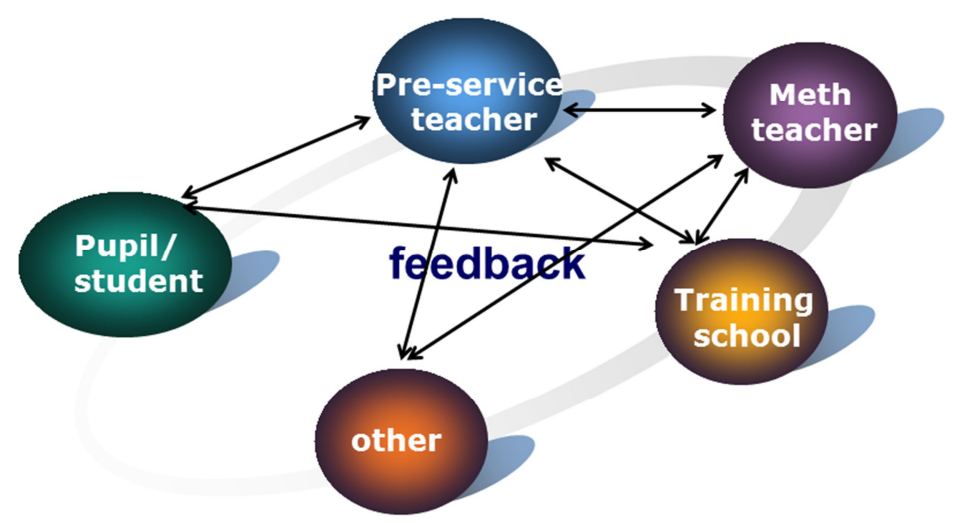

Fig. 8 Enriched feedback in LMS Moodle

Usually students who come for teacher training to schools are tabula rasa for supervisors. The eportolio with its components and artifacts such as lesson or study plans, critiques of the lessons, personal writings and reflections, student work samples can be useful tool for acquainting a student before he/she comes for teaching practice. This means that traditional reflection and discussion before and after the lesson student has to teach can be enriched. The additional value is that it is also a space for communication between the methodology teacher and supervising teacher.

This relation is an important connection of the academic and real world.

\section{Conclusion}

Teacher portfolio is the evaluation tool that can present the qualities of teacher. In case the portfolio should become a part of the institutional (school) culture it is necessary that teachers understand its value and do not perceive it as another burden or bureaucratic issue in their work. It might be useful not to set, prescribe the form (electronic or paper version), on the other hand it might be beneficial to set the compulsory sections (items), recommended and elective ones.

What is probably more important is the biggest strength of portfolio (as a source foe self-reflection) what is that teacher has to set the mirror to his/her work and to critically and constructively look at his/her activity. Its gradual improvement (recorded in the portfolio) is a motivating factor for his/her further development what is also reflected in his/her work, classroom atmosphere and their results. What more, VLE enables the broader community to enter the university space and thus to increase the objectivity of the owner's evaluation. This helps also to build teaching efficacy that influences teaching and learners. It is important to form the attitudes towards self-reflection (as a basis for self-evaluation, self-control, self-regulation, self-development) in the phase of pre-graduation period as those beliefs and habits have an effect later on their teaching efficacy and teaching itself.

\section{Acknowledgment}

This work was supported in part by a grant from KEGA 006PU-4/2012.

\section{References}

Anonymous. 2007. Porfolia v českých školách. [online]. Systémový projekt Kvalita I. Retrieved from http://www.esf-kvalita1.cz/portfolio/portfolia/skoly.php

Anonymous. 2013. The Teaching Center. [online]. Creating a teaching Portfolio. Retrieved from http://teachingcenter.wustl.edu/About/ProgramsforGraduateStudentsandPostdocs/resources/Pag es/Creating-a-Teaching-Portfolio.aspx 
Anonymous. n.d. TruCenter for Teaching Advancement and Assessment Reasearch. [online]. The Teaching Portfolio. Retrieved from http://ctaar.rutgers.edu/teaching/portfolios.html

Anonymous. n.d. Center for Teaching and Learning. [online]. Teaching portfolio. Assemble your teaching portfolio. The University of Texas at Austin. Retrieved from http://ctl.utexas.edu/teaching/peer_review/teaching_portfolio/assemble

Bandura, A. (1977). Social Learning Theory. New Jersey: Prentice Hall.

Bandura, A. (1997). Self-Efficacy: The Exercise of Control. New York: Freeman.

Barinková, K. \& MESÁRoŠOVÁ, S. (2011). Sebaúčinnost'. Psychologie a její kontext [online], 2(2), 155164. Retrieved from: http://psychkont.osu.cz/archiv/2-2-2011.htm

Crow, C. M. and C. Harrison, (2006). Developing the Cambridge ESOL Teacher Portfolio. Issues of Research Notes. 26. Retrieved from www.CambridgeESOL.org/rs_notes

Černotová, M. et al. (2010). Cviční učitelia. Prešov: FHPV PU

Černotová, M. (2000). Potrebujeme reformu v príprave učitel’ov? Pedagogický výzkum v ČR. Sborník př́spěvků z VIII. celostátní konference ČAPV. Liberec: TU v Liberci.

Edgerton, R., Hutchings, P., \& Quinlan, K. (1991). The Teaching Portfolio: Capturing the Scholarship in Teaching. Washington, DC: The American Association for Higher Education.

Filipková, B. (2012). Ako predchádzat' syndrómu vyhorenia a eliminovat' jeho príznaky v profesii pedagóga. [online]. Centrálny informačný portál rezortu školstva, Bratislava: VÚDPAP, Retrieved from https://www.iedu.sk/poradenstvo/Stranky/Pedagogicke.aspx

Gavora, P. \& Majerčíková, J. (2012). Vnímaná zdatnost' (self-eficacy) učitel'a: oblast' vyučovania a oblast' spolupráce s rodičmi. Pedagogicka orientace, 22(2), 205-221.

Gavora, P. (2008). Učitel'ovo vnímanie svojej profesijnej zdatnosti (self-efficacy). Prehl'ad problematiky. Pedagogika, 58(3), 222-235.

Gavora, P. (2010). Slovak Pre-service Teacher Self-Efficacy: Theoretical and Research Considerations. The New Educational Review, 21(2),17-30

Granberg, C. (2010). E-portfolios in teacher education 2002-2009: the social construction of discourse, design and dissemination. European Journal of Teacher Education, 33(3), 309-322.

Henning, C. \& Keller, G. (1996). Antistresový program pro učitele. Praha: Portál.

Herman, J. L. \& Winters, L. (1994). Portfolio Research: A Slim Collection. Educational Leadership, 52(2), 48-55.

Hupková, M. \& Petlák, E. (2004). Sebareflexia a kompetencie v práci učitel’a. Bratislava: Iris.

Kalhous, Z. \& Obst, O. (2002). Školní didaktika. Praha: Portál.

Kaplan, M. (1998). The Teaching Portfolio. [online]. The Center for Research on Learning and Teaching. University of Michigan. from http://www.crlt.umich.edu/sites/default/files/resource_files/CRLT_no11.pdf

Kyriacou, Ch. (1996). Klíčové dovednosti učitele. Praha: Portál.

Kyriacou, Ch. (2000). Essential Teachin Skills. Cheltenham: Nelson Thornes Ltd.

Newby, D. et al. (2007a). European Portfolio for Student Teachers of Languages. [online]. Council of Europe. Retrieved from http://www.ecml.at/epostl

Newby, D. et al. (eds.) (2007b). European Portfolio for Student Teachers of Languages - A reflection tool for language teacher education. Strasbourg, Graz: Council of Europe, European Centre for Modern Languages.

Pajares, F. (2002). Self-efficacy beliefs in academic contexts: An outline. Retrieved from http://des.emory.edu/mfp/efftalk.html

Palmer, P. (2007). The Courage to Teach: Exploring the Inner Landscape of a Teacher's Life. San Francisco: Jossey-Bass.

Petty, G. (1996). Moderní vyučování. Praha: Portál.

Petty, G. (2009). Teaching Today. A Practical Guide. London: Nelson Thornes.

Straková, J. (2005). Využití portfolia k hodnocení práce a výsledků žáků - část I. K čemu slouží různé typy portfolií. Moderní vyučování, 1(9), 6-7. 
Straková, J. (2005). Využití portfolia k hodnocení práce a výsledků žáků - část II. Pracovní portfolio. Moderní vyučování, 1(10), 8-9.

Straková, J. (2006). Využití portfolia k hodnocení práce a výsledků žáků - část III. Dokumentační portfolio. Moderní vyučování, 2(1), 6-7.

Straková, J., (2006). Využití portfolia k hodnocení práce a výsledků žáků - část IV. Prezentační portfolio. Moderní vyučování, 2(2), 6-7.

Straková, Z. (2010). Vybrané aspekty práce cvičného učitel'a. In Černotová M. et al., Cviční učitelia (n. p.). Prešov: Prešov University.

Šteflová, J. (2006). Portfolio učí poznat sebe sama. Učitelské noviny, 109(19), 10-11.

Takona, J. P. (2002). Pre-Service Teacher Portfolio Development. Lincoln: Writers Club Press.

Trunda, J. (2012). Profesijní portfolio učitele. Soubor metod k hodnocení a sebehodnocení. Praha: Národní ústav pro vzdělávání. http://www.nuov.cz/uploads/AE/evaluacni_nastroje/09_Profesijni_portfolio_ucitele.pdf

Ur, P. (2009). A Course in Language Teaching: Practice and Theory. Cambridge: Cambridge University Press.

Wolf, K., Whinery, B \& Hagerty, P. (1995). Teaching portfolios and portfolio conversations for teacher educators and teachers. Action in Teacher Education, 17(1), 30-39.

\section{Contact}

Assoc. prof. Ivana Cimermanová, PhD.

Institute of British and American Studies

Faculty of Arts, University of Prešov

17.novembra 1

08001 Prešov

SLOVAKIA

ivana.cimermanova@unipo.sk 